UDC 536

LBC 40.77

\title{
FEATURES OF HEATING POULTRY HOUSES WITH GAS STOVES
}

\author{
Aleksey V. Sklyar \\ OOO "Big Dutchman", Moscow, Russian Federation; \\ Big Dutchman AG (holding) Auf der Lage, Vechta, Germany \\ Iliya D. Korobko \\ Company ‘Stavropol broiler', Stavropol'skij Kraj, Blagodarnenskij rajon, the village of Burlats'koe \\ Margarita V. Postnova \\ Volgograd State University, Volgograd, Russian Federation
}

\begin{abstract}
Currently, modern poultry farms are located in regions with different climatic conditions. On this basis, the component of the electric power is great in power engineering, the combined heating and ventilating systems, lighting and local heating of poultry farms in the territory of the Russian Federation are based on these constructions. Analysis of energy costs of poultry farms showed that, of the estimated options to reduce the cost of electricity for poultry farms, one of the most effective can be an alternative source such as the generation of its own electricity. Naturally, for biological production with a continuous technological cycle, such as poultry farming, we are not talking about $100 \%$ replacement of power grids - they remain to cover $45-55 \%$ of the needs of the factory and serve as a reserve for the rest.
\end{abstract}

Key words: poultry products, heating, heaters, air, broiler.

УДК 536

ББК 40.77

\section{ОСОБЕННОСТИ ОТОПЛЕНИЯ ПТИЧНИКОВ ГАЗОВЫМИ ВОЗДУХОНАГРЕВАТЕЛЯМИ}

\author{
Алексей Владимирович Скляр \\ ООО «Биг Дачмен», г. Москва, Российская Федерация; \\ Big Dutchman AG (холдинг), Vechta, Германия \\ Илья Дмитриевич Коробко \\ ЗАО «Ставропольский Бройлер», Ставропольский край, Благодарненский р-н, с. Бурлацкое
}

\section{Маргарита Викторовна Постнова}

Волгоградский государственный университет, г. Волгоград, Российская Федерация

Аннотация. В настоящее время современные птицеводческие хозяйства размещаются в регионах с различными климатическими условиями. Таким образом, в энергетике велика составляющая электроэнергии, на которой базируются совмещенные отопительно-вентиляционные системы, освещение и локальный обогрев птицефабрик на территории РФ. Анализ энергозатрат птицефабрик показал, что из оцениваемых вариантов удешевления электроэнергии для птицеводческих хозяйств, одним из наиболее эффективных может быть альтернативный источник такой как выработка собственной электроэнергии. Естественно, для биопроизводства с непрерывным технологическим циклом, каким является птицеводческое хозяйство, речь не идет о 100 \% замещении электросетей - они остаются закрывать 45-55 \% потребностей фабрики и служить резервом остальному.

Ключевые слова: птицеводческая продукция, отопление, обогреватели, воздух, бройлер. 
В себестоимости птицеводческой продукции российских производителей (яйцо, мясо птицы и сотни пищевых изделий, в которых они используются) энергетические затраты третьи по вкладу. Это обусловлено тем, что в РФ самое «северное» промышленное птицеводство, которое в настоящее время дополняется растущей сетью крестьянско-фермерских птицеводческих хозяйств (ПХ) [1; 4]. В этом плане, минимизация отопительных затрат в ПХ РФ вопрос более чем актуальный, исходя из того, что российская птицеводческая продукция должна быть сравнимой по себестоимости с зарубежной хотя бы при защите собственного рынка страны от дешевого «куриного» импорта и тем более - при экспорте [2]. Ранее даже не все ПХ юга РФ обогревали птичники от автономных тепловых генераторов (ТГ-1,5 и ТГ-2,5), во всех остальных отопление обеспечивалось от центральных котельных с паровыми и водогрейными котлами через теплосети общей протяженностью до десятков километров с более чем существенными потерями тепла $(15 \ldots 28 \%)$ и трудозатратами на обслуживание [3; 5; 6; 7]. Массовый перевод ПХ на автономные системы обогрева птичников в промышленных и репродукторных цехах по всем регионам страны позволил существенно снизить затраты топлива. Вместе с тем, внедрение новых систем отопления по наиболее массовому варианту с газовыми воздухонагревателями (ВНГ по ГОСТ Р 50670-94) поставило вопросы:

а) возможного влияния выжигания кислорода и продуктов горения на продуктивность поголовья;

б) безопасной эксплуатации газовой аппаратуры с пламенными горелками в цехах с птицей и обслуживающим персоналом;

в) обеспечения нужного уровня ветеринарной и санитарной защиты поголовья на принципиально иных «вакуумированных» отопительно-вентиляционных системах.

Эксплуатация первых импортных («Джет Мастер» - «Эрмаф», «Газолек» и т.п.) и отечественных («Самум», ВГС-200, ВГ-0,07) комплектов ВНГ показала, что мощный комплекс защит делает такие обогреватели абсолютно безопасными: при перерывах в снабжении и недопустимых отклонениях от нормы в газовых и электросетях, погасании пламени, оста- новке вентилятора, перегреве корпуса и утечках газа в птичнике воздухонагреватели и газопровод низкого давления в птицеводческом зале отключаются (для сравнения - в газовых брудерах защита лишь по 2 параметрам). Позднее, после массовой реконструкции сотен птичников, надежность такого отопления была подтверждена стабильной работой тысяч обогревателей. Неоднократная аттестация ВНГ в Центрах испытания газоиспользующего оборудования (городов Москва, Нижний Новгород, К-Шахтинский) показала, что конструкции их горелок обеспечивают уровни «недожига» продуктов горения в выбросных газах существенно меньше ПДК по ГОСТ 12.1.005-88 (например, в российском ВГС: по СО - до 6, против 20 мг/м3, по NOx в пересчете на $\mathrm{NO}_{2}-$ 1,5 в сравнении с 5,0 мг/м3). Помимо оптимизации конструктивных параметров горелок для качественного дожига топлива, исключение возможности отравления людей и птицы окисями углерода и азота обеспечивается еще и за счет интенсивной аэрации птицеводческих залов. Это связано с тем, что для поддержания в пределах ПДК выдыхаемой птицей углекислоты до 0,25 \% в помещении, воздух птичника заменяется не менее 4-6 раз в час даже в периоды холодовых «пиков» (между расчетной наиболее холодной 5-дневкой и абсолютным минимумом), также способствуя минимизации уровней $\mathrm{CO}$ и NOx. К этому надо добавить, что есть серийные отечественные (ВГС-200 и др.) и зарубежные (AVS-Aerstream Ventilation Sistems и пр.), которые оснащаются радиальными вентиляторами и рассчитываются в том числе на работу в режиме наружного воздухозабора. Это дает возможность работать с такими ВНГ (или в сочетании их с рециркуляционными) в стартовый период выращивания птицы на положительном давлении воздуха в помещении, что особо ценно для ветеринарного и санитарного блокирования любого птицеводческого зала от негативного влияния выбросов воздуха из соседних птичников. В санитарнозащитном плане все типы ВНГ активно санируют птичник - за час несколько раз пропускают весь объем воздуха через горелки, что позволяет постоянно поддерживать уровень обсемененности воздуха в таком птицеводческом зале ниже ПДК (до 60 тыс. микробных тел - условно патогенных коли, стафилококков). 
Для прямого сжигания $1 \mathrm{~m}^{3}$ сетевого газа (ГОСТ 5542-87) в птичнике нужен кислород из 9,45 м 3 воздуха. Для проверки возможности влияния подобного выжигания $\mathrm{O}_{2}$ на продуктивность птицы на ПФ «Бурлацкая» (Ставропольский край) было проведено сравнительное выращивание бройлеров:

- 1-й птичник отапливали BHГ AVS с горелками прямого нагрева воздуха;

-2-й контрольный птичник-теплогенератором ТГ-2,5 с рекуперативным нагревом воздуха через стенку теплообменника.

Все остальные параметры в опыте и контроле были одинаковы - бройлерники размерами $84 \times 12 \times 3$ м с батареями Л-121 (Р-15, фирма «Перлеберг»), опыт выполнялся на применявшемся фабрикой бройлерном кроссе «Анак», живая масса суточных цыплят 39 ... 41 грамм, удельная посадочная площадь $423 \mathrm{~cm}^{2} /$ гол.

В первом птичнике опытные клетки были размещены непосредственно под ВНГ, во втором контрольные клетки были выбраны в аналогичных зонах помещения. За 43 дня откорма в контрольной и опытной партиях, средняя живая масса птицы, соответственно, составляла 2005+/-48 и 2025+/-51 граммов (среднесуточные приросты 45,7 и 46,1 грамма, конверсия 1,86 и 1,87 к.е./кг). Живая масса в опыте даже несколько выше контроля при недостоверной разнице $-\mathrm{P}<0,05$. Í àäåæí î ènêeëp ‘àoü âėèỹí èå âû æèãài èÿ Î нагревателями позволяют относительно небольшое снижение уровня кислорода в воздухе птицеводческого зала при работе всех горелок $\left(20,8 \% \mathrm{O}_{2}\right.$ вместо $\left.21 \%\right)$, а также интенсивный воздухообмен в птичнике даже в холодный период года (7-15 т.м $3 /$ ч при объеме здания всего $3700 \mathrm{~m}^{3}$ ). Работа с ВНГ требует неукоснительного соблюдения норм аэрации - иначе неизбежны загазованности выше ПДК по $\mathrm{CO}_{2}$, NOx (на начальной стадии массового внедрения ВНГ это отмеча- ли по ряду ПХ - Ивановский бройлер и др.). В целом перевод птицеводства РФ в том числе в северных регионах на локальное отопление птичников с уходом от центральных котельных позволил существенно сократить затраты на энергетику в себестоимости птицеводческой продукции, что немаловажно в условиях рынка.

\section{СПИСОК ЛИТЕРАТУРЫ}

1. Автоматизированная система обеспечения микроклимата в птичниках / И. М. Довлатов, Л. Ю. Юферев, В. В. Кирсанов, Д. Ю. Павкин, В. Ю. Матвеев // Вестник НГИЭИ. - 2018. № 7 (86). - C. 7-18.

2. Гаджиев, Р. М. Расход теплоты в отапливаемом птичнике / Р. М. Гаджиев // Аграрная наука. 2015. - № 4. - C. $28-29$.

3. Михалев, П. В. Эффективность применения новых методов контроля микроклимата при выращивании цыплят-бройлеров / П. В. Михалев, Н. М. Василевский // Ученые записки Казанской государственной академии ветеринарной медицины им. Н.Э Баумана. - 2012. - Т. 212. - С. 319-323.

4. Санжарновская, М. И. Экономия энергии в птичниках с помощью оптимизации вентиляционно-отопительных систем / М. И. Санжарновская // Инженерно-техническое обеспечение АПК. Реферативный журнал. - 2008. - № 4. - С. 1172.

5. Сливной, В. Н. Воздушное отопление птичников на птицефабрике работающей на биогазе / В. Н. Сливной, Д. В. Карнаух, Ю. И. Кирсанов // Сборник материалов XVI международной научно-практической конференции «Природные и интеллектуальные ресурсы Сибири, СИБРЕСУРС 2016». - 2016. - С. 105

6. Тимченко, В. А. Оптимальные системы отопления для птичников / В. А. Тимченко // Птица и птицепродукты. - 2011. - № 4. - С. 54-57.

7. Троханяк, В. И. Моделирование температурного поля с помощью MATLAB SIMULINK системы микроклимата в птичнике в зимний период года / В. И. Троханяк // APRIORI. Серия: Естественные и технические науки. - 2016. - № 6. - С. 26. 


\section{Information about the Authors}

Aleksey V. Sklyar, Candidate of Sciences (Agriculture), Official Agent, Big Dutchman AG (holding) Auf der Lage 249377 Vechta-Calveslage Postfach 116349360 Vechta, Germany, vsklar41@mail.ru.

Iliya D. Korobko, General Director, Company 'Stavropol broiler', Stavropol'skiy Kray, Blagodarnenskiy rayon, the Village of Burlats'koe, 356401, vsklar41@mail.ru.

Margarita V. Postnova, Doctor of Biological Sciences, Chief, Department of Bioengineering and Bioinformatics, Volgograd State University, Prosp. Universitetskiy, 100, 400062 Volgograd, Russian Federation, postnova@volsu.ru.

\section{Информация об авторах}

Алексей Владимирович Скляр, кандидат сельскохозяйственных наук, представитель, OОО «Биг Дачмен», г. Москва, Российская Федерация; Big Dutchman AG (холдинг) Auf der Lage 249377 Vechta-Calveslage Postfach 116349360 Vechta, Германия, vsklar41@mail.ru.

Илья Дмитриевич Коробко, генеральный директор, ЗАО «Ставропольский Бройлер», Ставропольский край, Благодарненский р-н, с. Бурлацкое, 356401, vsklar41@mail.ru.

Маргарита Викторовна Постнова, доктор биологических наук, старший научный сотрудник, заведующая кафедрой биоинженерии и биоинформатики, Волгоградский государственный университет, пр. Университетский, 100, 400062 г. Волгоград, Российская Федерация, postnova@volsu.ru. 